\title{
A Personal Name Etymology and a Shakespearean Dramatic Motiv
}

\author{
RICHARD A. COATES
}

$\mathrm{T}$

HE FEMALE PERSONAL NAME IMOGEN is first recorded as the name of the heroine of Shakespeare's Cymbeline, the daughter of the king of that name. Partridge 1936 and Attwater 1939 treat the form as of obscure origin. Partridge (op. cit.) suspects it of covert Old English ancestry. Attwater is content to agree and to note that no saint bears the name. Yonge (apud Partridge) links the name with that of Ygnoge, daughter of Pandrasus and wife of Brutus in Geoffrey of Monmouth's Historia regum Britanniae (see Thorpe 1966:62). This name appears in Holinshed's digest of Geoffrey as Innugen or Innogen (1577:12), and Weekley consequently suspects a printer's error for the double- $n$ form in the first folio (Weekley 1948:55fn). Sleigh and Johnson's popularising work (1962) repeats Weekley's view, and the authors invite us to consider an intended or subconscious associative link with the word "innocence." This is quite obviously appropriate in the context of Cymbeline, but whether it is a justifiable etymological assumption is a separate matter. These authors, falling back on Yonge 1863:45, raise the name Imagina, borne by the Duchess of Luxembourg around 1400. This is a red herring, being obviously an $a$-derivative of the Latin oblique stem imägin- (nom. sg. imāgo) "image," with presumably mariolatrous associations. More seriously, since Ygnoge is a British-Celtic princess (Weekley cites a Breton parallel to the name), Förster looks to the Irish ingen "daughter," and ultimately to the Greek ḱyóm "granddaughter" for * enigena. Withycombe 1950 cites this view without dissension.

Long 1878:122; 1883:91 chooses the less recherché and perhaps obvious derivation from an unattested Latin *imo(?)-gen(a) "lastborn," on the analogic lines of primigenus "firstborn." Popularising works (Swan 1900, Sleigh and Johnson [op. cit.]) quote this view, the latter stating that the given gloss is the "only possible" interpretation for the unattested Latin form. Since they adhere to the Weekleyan printer's error theory, they presumably feel that even this only possible interpretation is unintended. I believe that the "obvious" derivation from *imo(?)-gen(a) is correct, but that the presumed unique interpretation "lastborn" is only half correct. It is impossible to disprove absolutely the Celtic origin plus printer's error theory, but there is considerable cir- 
cumstantial evidence from within Cymbeline against it. Let it be said here that Shakespeare clearly went out of his way to deploy the name he chose in this context, for the historical Cymbeline had no daughter Ygnoge or Imogen in Holinshed, and the historical Ygnoge had no connection whatever with Cymbeline (i.e. Cunobelinus, tribute king to the Romans). This should lead us at once to suspect that Shakespeare may have deliberately altered a name from a different point in Holinshed to suit his purposes, or have invented a suitable name having only a fortuitous resemblance to that of a separate historical character. One of these possibilities seems highly probable in the light of what follows.

Given that *imo(?)-gen $(a)$ is a potentially meaningful Latin form, then one of its potential meanings is undoubtedly "lastborn"; imus is a superlative of inferus, whose comparative inferior appears in Cicero meaning "later, younger." In Ovid, the form imus is linked with mensis to mean the "last month." This should, however, in no way blind us to the fact that the more frequent meaning of this adjective paradigm is "low, lower, lowest," or even "wretched, etc." Livy has "inferioris iuris magistratus," Caesar "inferior animo"; infimus, the alternative superlative form of inferus, can be glossed as "abject" in Livy's "precibus infimis," and Cicero appends it to "faex populi." Ovid contrasts imus directly with superus "highest" in describing ranks of deities. Horace's "ad imum" ("to the bitter end") is an extended usage, and the nominalisation is found also in Vergil's "ima petens." It will be readily conceded that a second interpretation for *imo(?)-gen(a) on literal grounds is "lowest-born."

Imogen's husband in Cymbeline is Posthumus. Interestingly enough, a similar ambiguous meaning-potential to the one just described can be seen in this Latin word also. The general meaning of postumus, when predicated of personal names, is "lastborn," particularly when the bearer of the name was born after the death of his father (Cicero, Vergil). However, Cicero's "homines postumi" is unambiguously "the basest or most wretched men." The same author's "nihil posterius" may serve to indicate a similar duality of meaning for the comparative form when it is seen against his "posteriores cogitationes" ("subsequent, i.e. second thoughts"). It is as well here to note Tertullian's derivative nominalisation postumatus "low estate," even though this form is nonclassical. It is an extension of usages that were clearly current in golden age literature. In Cymbeline, Imogen and Posthumus are married to each other against her father's wishes. Both are literally the lastborn, Imogen of Cymbeline and his first wife (who died bearing her) and Posthumus of Sicilius Leonatus (who died of sorrow before Posthumus' birth at the death of his two elder sons in battle). His mother is also dead. Posthumus and Imogen are brought up at Cymbeline's court as "playfellows" (Cym. 1i). Posthumus is treated by Cymbeline as if his own 
child. They start out therefore as quasi-equals. Both have two apparently deceased elder brothers; both are motherless. Both have a position to fall from, therefore, at "the court ... whose top to climb / Is certain falling," ( 3 iii) and in the discussion that follows these remarks, it will be seen that the notion of "baseness, social debasement" is used as a dramatic motiv by Shakespeare throughout the play. Beside the literal similarities in the life-histories of the protagonists, the references to Posthumus' attributes (strictly speaking he has no rank) bear significant parallels to each other. If Imogen is "divine Imogen" ( $2 \mathrm{i}, 3 \mathrm{vi})$ and "more goddess-like than wife-like" ( 3 ii), then Posthumus

$\mathrm{He}$ is sits 'mongst men like a descended god. (1 vi)

she is most like a noble lord in love (5 v);

the noble Imogen (5i).

The difference lying in the straightforward predication of these qualities of Imogen and their attribution by simile to Posthumus can be seen as a direct reference to their actual difference of rank. But far more significant than these parallels, in terms of the frequency of their occurrence, are the denials of the characters' rank or status. The motivword "beggar" is used of Posthumus at many points in the play. Cymbeline says to Imogen of her unsanctioned marriage to Posthumus:

Thou took'st a beggar; wouldst have made my throne

A seat for baseness. (1 i)

Iachimo describes her as

taking a beggar without less quality ( 1 iv),

and to her face lyingly reports Posthumus' unfaithfulness using the phrase

the beggary of his change. (1 vi)

Cloten, Imogen's stepbrother, interprets Cymbeline's acceptance of the orphan Posthumus as a mere act of charity. Posthumus is

that base wretch, -

One bred of alms and fostered with cold dishes,

With scraps o' the court. ( 2 iii)

Who more than he more mean? (ibid.)

Further, it is allowed only to the lowly to marry for love, which Imogen and Posthumus have done, because on them

there is no more dependency

But brats and beggary. (ibid.) 
Later, also from Cloten's mouth, Posthumus is "the low Posthumus" and "that beggar Posthumus" (3v).

When Iachimo, the wagerer against Imogen's honour, is disarmed by the disguised Posthumus in 5 ii, although he does not recognise his conqueror, the beggary motiv is resumed with dramatic irony:

The heaviness and guilt within my bosom

Takes off my manhood . . .

or could this carl,

A very drudge of nature's, have subdu'd me

In my profession? . . . .

If that this gentry, Britain, go before

This lout as he exceeds our lords, the odds

Is that we scarce are men, and you are gods.

Posthumus is referred to by Imogen, who believes him to be dead when she sees the disguised corpse of Cloten, as Richard du Champ. It would be facile to assume that Shakespeare intended a name for him with literally rustic content as part of the continuing dramatic motiv of non-courtliness/non-aristocracy. Nevertheless it could be seen as an anticipation of Posthumus' later disguise:

I'll disrobe me

Of these Italian weeds, and suit myself

As does a Briton peasant. (5 i)

The name is a disguise here, just as the literal disguise is introduced in the above quotation.

Whilst Posthumus clearly has a social duality as a

poor but worthy gentleman (1 i)

the two aspects of his upbringing have different status in the play. In $5 \mathrm{i}$, his literal disguise as a peasant is an externalisation of the notion that his poverty cloaks a fundamental worthiness. His real weak political position at court is emphasized only by those who have some reason to be against him (Cymbeline the slighted king, Cloten the failed suitor, Iachimo with his early low opinion of Posthumus and his later plot against him, cf. above). The most telling lines of the play in this respect occur in $3 \mathrm{vi}$, where Imogen says:

Two beggars told me

I could not miss my way: will poor folks lie, That have afflictions on them, knowing 'tis A punishment or trial? ...

to lapse in fulness 
Is sorer than to lie for need; and falsehood

Is worse in kings than beggars.

Imogen lies from a position of weakness (about her master's name, when disguised in order to make her escape from the court; cf. above), but lies in the play also come from the mouths of the idle advantaged, such as Iachimo, whose only interest in the situation of Imogen and Posthumus is his possible success in the frivolous wager on Imogen's honour.

Bless'd be those,

How mean soe'er, that have their honest wills. (1 vi)

This play makes futher reference to inborn characteristics of the various social ranks ${ }^{1}$, even in situations where the speakers themselves are unaware of their privileged birth; the King's long-lost true sons, Guiderius and Arviragus, have a natural patriotic response to their country's danger, and an unconscious sense of kinship with their unrecognised sister Imogen. Given this, we should not be surprised to find truth and lack of dissimulation held up as similarly inherent properties of those destined to and fit to rule. Cloten, the King's stepson, "lapses in fulness" when he disguises himself as Posthumus in order to gain his revenge, because he dissimulates in a position of relative power; Imogen and Posthumus (cf. the other parallels above) both assume disguises to protect themselves in positions of weakness or persecution, and in pursuit of the restitution of rightful positions (e.g. their married status, and the rightful courtly position which their characteristics guarantee them) i.e. they "lie for need." By contrast, Guiderius finds Cloten

not seeming

So worthy as thy birth (4 ii)

when he is disguised in pursuit of Imogen with the intention of raping her.

Imogen, despite her literal high political rank and the appropriate attributes of it, also adopts the dramatic motiv of shift of rank during the course of the play:

Would I were

A neatherd's daughter, and my Leonatus (i.e. Posthumus, RC)

Our neighbour's shepherd's son! (1 i)

She accuses Cloten of

(putting) me to forget a lady's manners. (2 iii)

Her initial disguise is that of a "franklin's housewife" ( 3 ii), and Belarius

${ }^{1}$ Cf. "Cowards father cowards .... ." (4 ii). 
the magician picks up the term with dramatic irony when she is disguised and on the run as the pageboy Fidele:

Pray be not sick,

For you must be our housewife. (4 ii)

She first meets Belarius when she is a potential beggar,

(thinking)

To have begg'd or bought what I have took. (3 vi)

She is variously described as "disloyal," "vile" (1 i), "whore” (2 iv), "wretched" (3 vi), all terms which have strong social implications. The Queen, her stepmother, makes great play of Imogen's supposed failures of service to the king in his royal rather than his paternal capacity $(3 \mathrm{v})$; whereas at the dénouement, Imogen voluntarily offers service to the King (5 v). As with Posthumus, Imogen's downward social shifts are either assigned to her by lie or misleading evidence, or are else metaphorical, being concomitant with the pursuit of the rightful order of things. Imogen's social duality, unlike Posthumus', is entirely metaphorical; Posthumus' has a partly literal basis.

It is possible to see Imogen's metaphorical sex-change, her disguise as a boy, as a shift of rank also; but rather this is a lie from a position of weakness, an excusable act in her philosophy, as we have already ascertained.

For all characters, the social stepdown motiv is metaphorically applied when Posthumus exclaims, hearing of Imogen's supposed unfaithfulness for the first time:

We are all bastards;

And that most venerable man which I

Did call my father was I know not where

When I was stamped. (2 v)

Given this complex use of the motiv of social debasement, it is possible to see both names, Posthumus and Imogen, as ambiguous throughout the play. Literally both are lastborn. Both shift in social position in pursuit of the legitimate order, and both are reviled in terms relating to low social rank. Both are therefore ironically named "lowest-born," in accordance with the notion that names may be a cloak or a disguise for an underlying reality.

It is instructive to compare the name Cloten (surely originally pronounced $^{2}$ ['klotṇ] and not ['kləutn], cf. Kökeritz 1959:43, and "Cloten's clotpoll" [4ii]). The name is divorced from its probable

${ }^{2}$ Transcription in accordance with the principles of the alphabet of the International Phonetic Association, and Gimson 1962. 
etymology. Obermüller 1868:354 cites a form clutam, which he derives (suspectly) from Old Irish cloth-am(hain) "fame-man"; but the form is indeed probably related to the Celtic forms of the same stock as "fame," cf. reconstructed Old Celtic *klutos "famous" (Förster 1921:71), and Middle Welsh clot(fawr) "celebrated" (Lewis and Pedersen 1937:76). There is not the slightest reason to assume that Shakespeare was acquainted with the Celtic etymologies of his characters' names; indeed, much linguistic ingenuity was still being deployed in the sixteenth and seventeenth centuries with the intention of deriving all the world's languages from a common source, e.g. Hebrew; thus the very concept of a Celtic etymology can have been at best nebulous until Lhuyd's pioneering work (1707). We may assume Shakespeare intended his literate audience to work out obvious Latin (and perhaps Greek) etymologies for themselves and to draw appropriate conclusions from them; whilst they would provide non-classical, e.g. plain English, etymologies $^{3}$ for those names with no obvious Latin/Greek congeners, e.g. Cloten. Cloten is thus surely to be related with $\operatorname{clot}\left(\right.$ poll) and clod. ${ }^{4}$

Equally we may conclude that Imogen is no Celtic or English name, but rather one of those names for which an audience could justifiably be expected to provide etymologies from Latin. It is an ambiguous name "last/lowest-born." It may have been partly suggested by the name of a British princess who had nothing to do with the Cymbeline story, but this is irrelevant to the immediate etymology of the name.

\section{Cambridgeshire College of Arts and Technology and Queens' College Cambridge, England}

\section{References}

Attwater, D. (compiler) Names and name-days. London: Burns, Oates and Washbourne Ltd., 1939.

Förster, M. Keltisches Wortgut im Englischen. Halle: Niemeyer, 1921.

Gimson, A.C. An Introduction to the Pronunciation of English. London: Arnold, 1962.

Holinshed, R. The historie of England, 1577.

Kökeritz, H. Shakespeare's pronunciation. New Haven: Yale University Press, 1953.

Kökeritz, H. Shakespeare's Names: a Pronouncing Dictionary. New Haven: Yale University Press, 1959.

Lewis, H. and Pedersen, H. A Concise Comparative Celtic Grammar. Göttingen, 1937.

\footnotetext{
${ }^{3}$ Or at any rate associations.

${ }^{4}$ Cf. Kökeritz 1953:71; 1959:43. The first folio spelling is Clotten.
} 
Lhuyd, E. Archaeologia Britannica. Vol. 1. Oxford, 1707.

Long, H.A. The Names we Bear. Glasgow: W. Macrone, 1878.

Long, H.A. Personal and Family Names. London and Edinburgh: Hamilton Adams and Co.; J. Menzies and Co., 1883.

Obermüller, W. Deutsch-Keltisches Wörterbuch. Vol. 1., 1868; photocopied edition, Wiesbaden, 1967.

Partridge, E.H. Name this Child. London: Hamish Hamilton, 1936.

Shakespeare, W. Cymbeline. London: Nonesuch edition based on first folio text. Harrap \& Co., 1953.

Sleigh, L. and Johnson, C. The book of girls' names. London: Harrap \& Co., 1962.

Swan, H. Girls' Christian Names. London: Swan, Sonnenschein and Co., 1900.

Thorpe, L. Geoffrey of Monmouth: The History of the Kings of Britain. Harmondsworth: Penguin. Penguin Classics, 1966.

Weekley, E. Jack and Jill: a Study in our Christian Names. London: J. Murray, $1948^{2}$.

Withycombe, E.G. Oxford Dictionary of English Christian Names. London: Oxford University Press, $1950^{2}$.

Yonge, C.M. History of Christian Names. Vol. 2. London: Parker, son and Bourn, 1863.

\section{EIGHTH ANNUAL CONFERENCE On INDIANA PLACE-NAMES}

The Eighth Annual Conference on Indiana Place-Names will be held on June 18, 1976 at Indiana State University, Terre Haute. The program includes papers on Fayette County place-names, Wabash County place-names, Montgomery County place-names and on the pronunciation of Indiana place-names and begins at 9:30 in Dreiser Hall \#3. At the end of the morning program will be a luncheon; afterward, a colloquium on Indiana place-name research. Program chairman is Professor Ronald L. Baker of the department of English and Journalism. 